\title{
Industrial chemical accidents: a growing health hazard in the Islamic Republic of Iran
}

\author{
Farin Fatemi, ${ }^{1}$ Ali Ardalan, ${ }^{2,3}$ Nabiollah Mansouri, ${ }^{4}$ Benigno Aguirre ${ }^{5}$ and Iraj Mohammdfam ${ }^{6}$
}

${ }^{1}$ School of Public Health, Semnan University of Medical Sciences, Semnan, Islamic Republic of Iran. ${ }^{2}$ Department of Disaster and Emergency Health, School of Public Health, Tehran University of Medical Sciences, Tehran, Islamic Republic of Iran (Correspondence to: Ali Ardalan: aardalan@tums. ac.ir). ${ }^{3}$ Harvard Humanitarian Initiative, Department of Global Health and Population at Harvard School of Public Health, Harvard University, Cambridge, Massachusetts, United States of America. ${ }^{4}$ Department of Health, Safety, Environment (HSE), Science and Research Branch of Islamic Azad University, Tehran, Islamic Republic of Iran. ${ }^{5}$ Disaster Research Center, University of Delaware, Newark, Delaware, United States of America. ${ }^{6}$ Department of Occupational Health, School of Public Health, Hamadan University of Medical Sciences, Hamadan, Islamic Republic of Iran.

\begin{abstract}
Background: Occupational chemical accidents have increased in recent years in the Islamic Republic of Iran. In June and August 2015, three large explosions occurred at chemical warehouses in Rey, Tehran Province, and toxic vapours were released.

Aims: This study reviewed the three chemical accidents and assessed the extent to which the requirements for chemical safety and preparedness for chemical incidents under the International Health Regulations (IHR) are in place, and implemented at local and national levels in the Islamic Republic of Iran.

Methods: Data were obtained from secondary data and field visits to selected chemical plants. The secondary data were used to complete a 33-item checklist based on the IHR and the Ministry of Health and Medical Education checklist. A sample of 15 warehouses in Kahrizak district, Rey County, were visited to assess their capacity in relation to the IHR using a 15-item checklist.

Results: Some weaknesses were seen in the IHR capacity in the study area. The main weaknesses were lack of an effective surveillance system for chemical accidents and low levels of safety in chemical plants and warehouses. Other weaknesses included the lack of awareness of residents about chemical hazards and poorly equipped health centres for the management of victims of chemical accidents. The study area was not prepared for chemical accidents both within industrial plants and residential areas.
\end{abstract}

Conclusions: Action is needed to improve the areas of weakness so as to achieve the necessary capacities for chemical safety, and preparedness and response to chemical incidents in line with the IHR.

Citation: Fatemi F; Ardalan A; Mansouri N; Aguirre B; Mohammdfam I. Industrial chemical accidents: a growing health hazard in the Islamic Republic of Iran. East Mediterr Health J. 2019;25(1):5-11. https://doi.org/10.26719/2019.25.1.5

Received: 13/06/16; accepted: 16/07/17

Copyright @ World Health Organization (WHO) 2019. Some rights reserved. This work is available under the CC BY-NC-SA 3.0 IGO license (https:// creativecommons.org/licenses/by-nc-sa/3.0/igo).

\section{Introduction}

The Islamic Republic of Iran is a developing country with a lot of capacity in the manufacturing sector. Industrialization has been growing quickly because of market demands in the country $(1,2)$. Rapid industrialization without the provision of established infrastructures to prevent industrial accidents can cause problems for countries (3-5). The statistics on industrial chemical accidents have shown an increase in accidents between 2010 and 2013 in the Islamic Republic of Iran (6). Figure 1 shows the distribution of industrial chemical accidents in the Islamic Republic of Iran between 2010 and 2013 according to type and number. In addition, in 2014, over 230 people were hospitalized for the release toxic gases in the city of Zahedan, in the south of the country (7).

In some industrial cities of the Islamic Republic of Iran, the distance between chemical installations and residential areas has not been taken into consideration (8). As a result, concern is growing about the public health effects of chemical plants, particularly the release of chemicals, as happened at Flixbrough, Bhopal and Seveso (9-13).

The province of Tehran has 38 counties and Rey is one of the largest and most industrial of them. In June and August 2015, 3 large chemical incidents occurred in Rey.

\section{Case 1}

A fire broke out at a warehouse at kilometre 3 of the Qom-Tehran road on the morning of Friday, 12 June 2015. The blaze was caused by a tanker containing chemical liquids which then extended to 11 other chemical tankers that were parked in the 4000 square metres of the warehouse. Police and firefighters put out the fire within 4 hours. More than 250000 L of chemical liquids completely burned which resulted in the release of toxic vapours several kilometres away from the warehouse where the incident occurred. Three firefighters had minor chemical burns to their skin and were taken to the hospital but there are no data on injuries, such as respiratory distress, and eye and skin irritation in the residents of the area. 
Explosion

Fire

Release and exposure

Poisoning

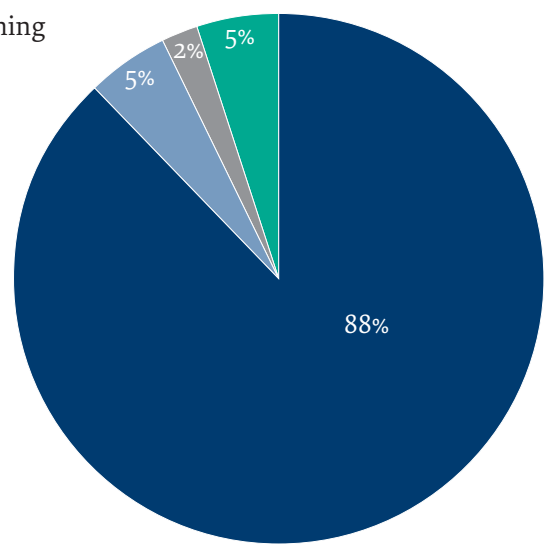

Figure 1 Distribution of industrial chemical accidents according type in the Islamic Republic of Iran, 2010-2013 ( $n=16$ 386)

\section{Case 2}

On the evening of Tuesday, 18 August 2015, a fire broke out at a chemical warehouse, with an area of 1500 square metres, in Kahrizak district. The local fire station requested help from the cities of Rey and Tehran, and 6 firefighters and 8 fire trucks were sent to the scene. The fire brigade stated that the fire was under control within 2 hours. A hazardous materials (Hazmat) team also accompanied the firefighting teams. There were no injuries to workers, residents or firefighters but one building of the warehouse was completely destroyed by fire and several tons of chemicals, including glycerin and raw materials, were damaged.

\section{Case 3}

On Thursday evening, 20 August 2015, 2 days after case 2, fire destroyed another chemical warehouse at the same place, Shourabad, Kahrizak. Many chemicals, sponges and large rolls of paper were stored in 2 buildings of the warehouse in over 6000 square metres. The local fire station called for help, and 4 teams of firefighters and 10 fire trucks managed to put out the fire within 3 hours. The emergency responders and residents were exposed to chemical vapours but there are no accurate data about the number of injuries.

Figure 2 shows the location of the 3 chemical accidents in June and August 2015.

The International Health Regulations (IHR) specifically deal with human health hazards. Chemical events such as fires, explosions, leakages or release of chemicals are health hazards that could have serious harmful effects on human health and the environment. Chemical events may affect human health directly or indirectly. Therefore, providing the minimum chemical core capacities under the IHR could help decrease human vulnerability in the areas at risk of chemical accidents.
The aim of this article was to identify compliance with the IHR for chemical safety management in industrial zones and the neighbouring residential areas in the Islamic Republic of Iran.

\section{Methods}

This study was conducted in 2015. The sources of data were secondary data and field visits. The secondary data included censuses, information collected by local health centres, regional health networks, organizational records, protocols and data that were originally collected for other research purposes. In order to complete the data, 15 chemical warehouses, out of 80 in Kahrizak, were randomly selected for a visit. We developed a 15item checklist, based on IHR core capacities, to complete during the visit to each selected chemical warehouse by observation (14). All field visits were conducted during 1 week in Kahrizak, Rey. We developed another checklist also based on IHR and the checklist of the Ministry of Health and Medical Education. This 33-item checklist was used to analyse the management of chemical events at the local and national levels. We also interviewed the local authorities and competent experts at the Ministry of Health and Medical Education, and reviewed available documents, reports and other literature (e.g. websites of the Ministry of Health and Medical Education and the Ministry of Labour) for information related to chemical accident management at local and national level in the Islamic Republic of Iran. We used content analysis for the subjective interpretation of the interviews to identify concepts, and the information from interviews and secondary data were used to complete the checklist.

The data collected were used to assess the extent to which the minimum requirements of the IHR for

\section{The case study geographical location}

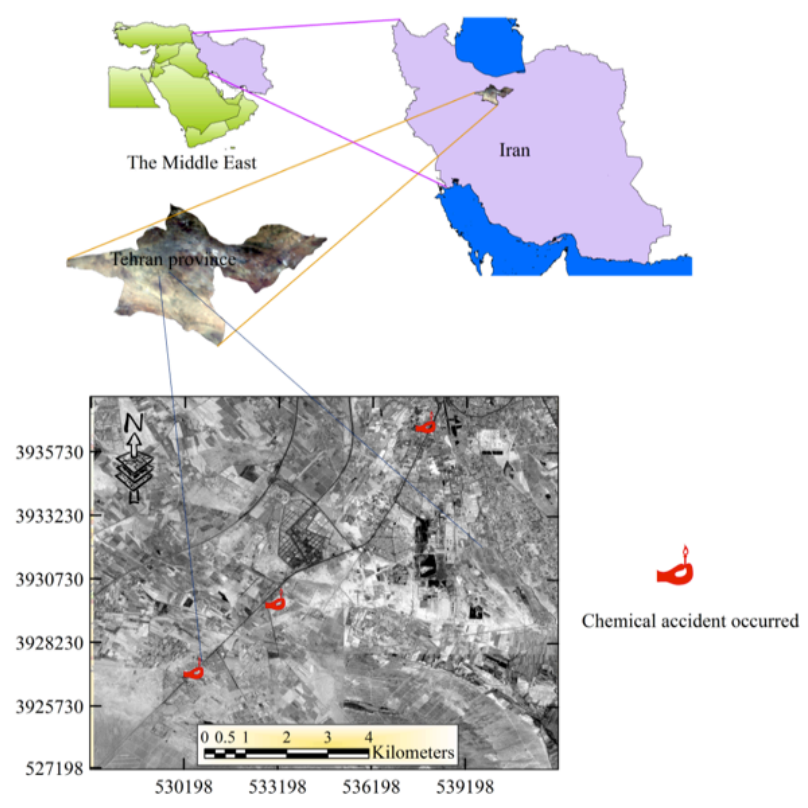

Figure 2 Location of the 3 chemical accidents in June and August 2015 
Has a risk communication plan for chemical incidents

Staff are trained on emergency responce to chemical

Reports chemical events to the Ministry of Health Alert levels for chemical events

Defines standard case for priority chemical events

Has material safety data sheets for all chemical

Has chemical expertise and resources

Has facilities of chemical health emergencies

Has a safety committee for management of chemical

Has coordinating mechanisms between chemical

Has a strategic plan for surveillance of and response

Implements the rules on chemical materials

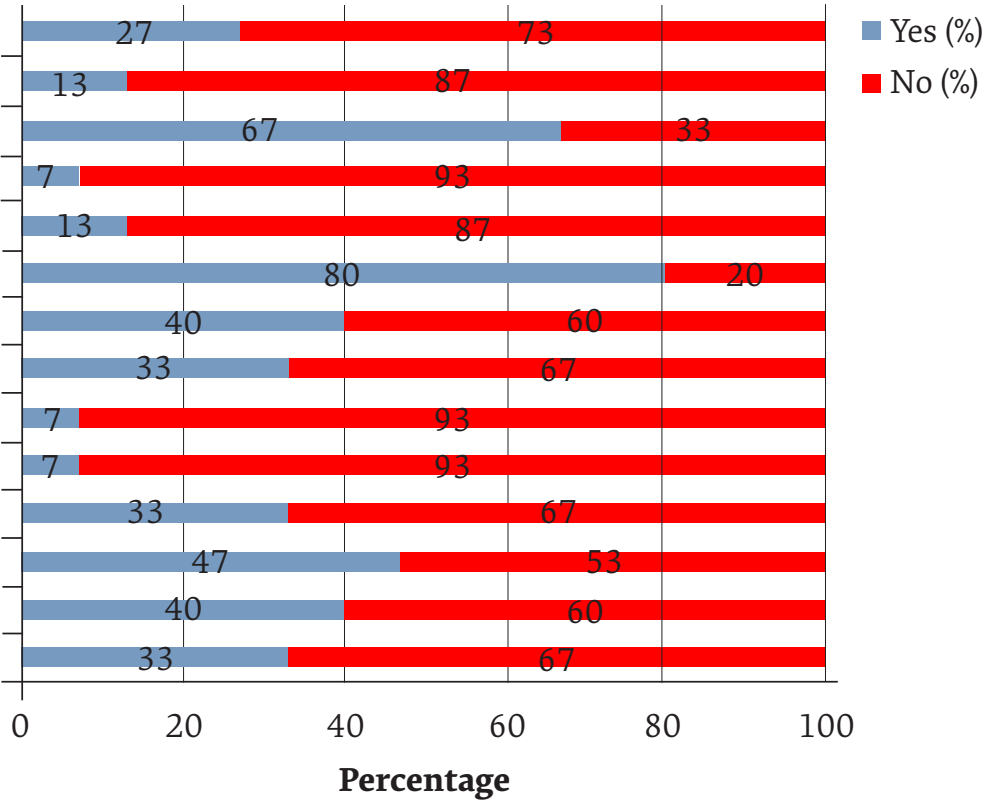

Figure 3 Proportion of warehouses meeting the requirements of chemical safety management, 2016

mitigation of chemical hazards were in place in the surveyed area and nationally.

\section{Results}

According to the field visits, more than of $80 \%$ of the warehouses had a material safety data sheet for all the chemicals they have stored and maintained. In addition, 10 of the 15 warehouses report their chemical events to the Ministry of Health and Medical Education. The IHR elements that were least present were: providing facilities such as equipped hospitals with trained staff for management of chemical health emergencies, having a safety committee at the workplace and having established alert levels for chemical events; only 1 of the 15 warehouses had these requirements in place (Figure 3 ).

The requirements for the management of chemical accidents were extracted from secondary data and using the health inspection checklist of the Ministry of Health and Medical Education. Some of these requirements are established at the national level but not at the local level because of weak supervision, the lack of a strategic plan or insufficient capacity to implement them. However, we tried to check the extent of implementation of the requirements by reviewing documents and through the field visits in order to analyse the management of chemical events in the country. In total, 7 of the 33 core elements required for the management of chemical incidents were present at national and local levels. Almost half (14) of the core elements of the checklist were not established at the national level or the local level. Also, 12 of the 33 core elements were established at the national level but not at the local level. The main differences between the national and local levels related to: having the required components for the management of chemical incidents, having a policy and road map for the surveillance of and response to chemical emergencies, having access to a hazmat team for chemical incidents and having case management and poison centres available for chemical exposures and poisoning (Table 1).

\section{Discussion}

The aim of this study was to explore compliance with the IHR related to chemical accidents which should be in place in industrial zones and the neighbouring residential areas. Our findings showed that the most important factor was the lack of a coordinated approach to prevent, prepare for, respond to and recover from chemical accidents in the area under study. Further investigations showed that the lack of a coordinated approach for management of chemical incidents was also evident at the national level. Implementing the core IHR capacities in the filed is the foundation for managing chemical incidents correctly.

The 6 main IHR capacities (14) were assessed.

\section{National legislation, policy and financing}

Chemical regulations, standards, codes and management systems were established after major accidents such as Seveso, Flixborough (15). At the present time in the Islamic Republic of Iran, there are chemical safety legislations for manufacturing, storing, transporting and using chemicals at the national level in order to prevent chemical events and harmful health effects on the general public (8). However, through our field observation and review of the relevant documents, there are clearly some difficulties in the implementation of the regulations. For example, there is a lack of adequate supervision by the authorities of chemical plants and warehouses at the local level, and a lack of knowledge updates, such as the use of a global harmonized system of classification and labelling of chemicals in companies and warehouses which are exposed to hazardous materials. In addition, chemical safety principles at work and in public environments were not a priority in chemical plants, probably because 


\begin{tabular}{|c|c|c|c|c|c|}
\hline \multirow[t]{2}{*}{ No. } & \multirow[t]{2}{*}{ Item } & \multicolumn{2}{|c|}{ National } & \multicolumn{2}{|c|}{ Local } \\
\hline & & Yes & No & Yes & No \\
\hline 1 & Legislation on surveillance and response to chemical events & & & & \\
\hline 2 & Policy for the surveillance of and response to chemical emergencies & & & & \\
\hline 3 & Policy for industrial waste management & & & & \\
\hline 4 & Strategic plan to strengthen the surveillance of and response to chemical events & & & & \\
\hline 5 & Operational public health plan for responding to chemical events & & & & \\
\hline 6 & Coordination mechanism between chemical safety and national health authorities & & & & \\
\hline 7 & $\begin{array}{l}\text { Coordination mechanism between chemical safety authorities and the International } \\
\text { Health Regulations }\end{array}$ & & & & \\
\hline 8 & Intersectoral committee/taskforce for management of and response to chemical events & & & & \\
\hline 9 & Inventory of potential hazard facilities for chemical health emergencies & & & & \\
\hline 10 & Inventory of chemical expertise and resources & & & & \\
\hline 11 & Assessment of chemical risks in chemical plants & & & & \\
\hline 12 & List of priority chemical events and syndromes for surveillance & & & & \\
\hline 13 & List of information sources for chemical events & & & & \\
\hline 14 & Manuals available for surveillance, investigation and control of chemical events & & & & \\
\hline 15 & Guidelines disseminated to relevant levels and stakeholders & & & & \\
\hline 16 & Standard definition of health hazard from chemical contamination of water & & & & \\
\hline 17 & Standard definition of health hazard from chemical contamination of air & & & & \\
\hline 18 & Standard definition of health hazard from chemical contamination of food & & & & \\
\hline 19 & Standard definition of health hazard from chemical contamination of others & & & & \\
\hline 20 & Standard case definitions for priority chemical events & & & & \\
\hline 21 & Multisectoral risk assessment during chemical event of public health concern & & & & \\
\hline 22 & Alert levels established for chemical events & & & & \\
\hline 23 & $\begin{array}{l}\text { Chemical events reported to the Ministry of Health and Medical Education as part of } \\
\text { surveillance }\end{array}$ & & & & \\
\hline 24 & Specified time frame for reporting urgent chemical events & & & & \\
\hline 25 & Hazmat team skilled in emergency response to chemical events & & & & \\
\hline 26 & Staff in related industries trained in emergency response to chemical events & & & & \\
\hline 27 & Case management centres for chemical exposures and poisoning & & & & \\
\hline 28 & Poison centres established & & & & \\
\hline 29 & Health staff trained in case management for chemical poisoning & & & & \\
\hline 30 & First responder staff trained in case management for chemical poisoning & & & & \\
\hline 31 & Risk communication plan for chemical incidents & & & & \\
\hline 32 & $\begin{array}{l}\text { Public health education on chemical accidents management, specifically for residents who } \\
\text { live near chemical plants }\end{array}$ & & & & \\
\hline 33 & Laboratory capacity to confirm the etiology of chemical events & & & & \\
\hline
\end{tabular}

the authorities are more concerned with industrialization and increasing the manufacturing output of factories.

\section{Coordination}

The effective implementation of relevant chemical regulations requires a multidisciplinary approach with partners and stakeholders in order to have effective alert and response systems. Developing a national chemical profile is a multisectoral effort that was started by the Iranian Ministry of Health and Medical Education in the past five years. However, it will not be possible to do this without the cooperation of other ministries, agencies, and govern- mental and nongovernmental organizations. In addition, efficient and effective management of the victims of a chemical incident depends upon a coordinated response between the Emergency Medical Services and other first responders (police and firefighters) who attend the scene (16).

\section{Surveillance}

Having an effective surveillance system for chemical accidents and their public health impact requires a strong reporting and analysis process (17). This surveillance system should be able to identify high-risk locations, provide 
early detection of major events, and plan an emergency response programme $(18,19)$. Surveillance and lessons learned from major chemical accidents may lead to new legislative and regulatory actions just as changes took place in the United States chemical safety legislation following Bhopal (17).

In the past 2 years, some measures have been adopted to integrate the surveillance system for chemical accidents into primary health care in the Iranian Ministry of Health and Medical Education. However, this requires the necessary infrastructure to be in place, such as communication lines, and equipped laboratories and hospitals in the areas exposed to chemical hazards. At the same time, the Ministry of Labour has its own surveillance system for chemical accidents. It would be more effective to coordinate and integrate the activities and systems of these 2 ministries.

\section{Preparedness}

Preparedness for chemical events includes the development of public health emergency response plans at national, regional and local levels. Chemical risk assessment at the hazardous sites, mapping of human vulnerability to chemical hazards, planning emergency evacuation if there is a disaster in residential areas, and the identification of available resources and capacities are other components of preparedness $(12,20,21)$.

Apart from the chemical plants seeking international certification, conducting risk assessment is not compulsory for the rest of the chemical installations in the Islamic Republic of Iran. However, risk assessment is a good opportunity to identify hazards and make local authorities focus more on the hazardous sites. Moreover, the authorities should include some private companies and factories, which have resources for chemical emergencies, in the local planning of this industrial district $(22,23)$. Having knowledge about what chemicals exist in the community, establishing a database, and providing appropriate training to health care workers and first responders in relation to chemicals are the first steps that should be taken for preparedness in the study area.

\section{Response}

Hazmat teams are essential for responding to the accidental or intentional release of dangerous chemical agents into the environment (24). Hazmat teams are also responsible for rapid assessment of the situation and controlling the operations to deal with such an event, including case management and the decontamination process in the area exposed to chemical accidents.

One of the priorities should be to establish and distribute hazmat teams in appropriate locations throughout the country so they are quickly available in the required areas when needed. Having a rapid response in the areas exposed to chemical accidents helps to mitigate later and worse effects $(12,25)$.

In addition, the public health service is responsible for public health protection against chemical incidents, and health care workers should have enough knowledge and capacity to manage the victims (26). At the present time, the Iranian public health system does not have specific training courses on chemical injuries for health workers. Furthermore, the health centres do not have the necessary capacity to manage chemical incidents.

\section{Risk communication}

Risk communication is a multilevel process which aims to sensitize stakeholders to chemical risk management in the areas that might be affected by chemical events (20). The stakeholders are different groups including the authorities, policy-makers and the general population. An essential part of risk communication is the dissemination of information to the public about chemical incidents, including their mitigation or relevant disease outbreaks (27). Risk communication should consider the social, religious, cultural, political and economic aspects associated with the chemical event (28).

All stakeholders in the country need to be identified for risk communication. A timely and robust communication mechanism should also be established to coordinate correct responses at the time of an incident. Because of the points mentioned earlier, any emergency communication plan needs to be developed and tested in the study area. In addition, risk communication to the population living in this area is essential. They should have information about hazards in the vicinity and the protective actions that they can benefit from if a chemical incident occurs. For instance, many lives would have been saved in Bhopal if people had been aware of the simple safety measure to stay in an enclosed space and put wet cloths on the face (23).

\section{Conclusion}

Our results show that Rey County is not well prepared for chemical accidents both in industrial and residential areas. The situation analysis of chemical warehouses in Kahrizak demonstrated weaknesses related to chemical hazards with regard to IHR capacities, including poor coordination among stakeholders in chemical legislation, few hazmat teams, the lack of an integrated chemical surveillance system, and the lack of preparedness among the general public and local health centres.

Further studies are needed on the risks to the population, and the action taken to rectify the weak points outlined in this report and to provide adequate capabilities at national and local levels in the 6 capacities of the IHR discussed. Determining the factors that make people vulnerable to chemical incidents could reduce the chemical harm within the chemical plants and also to the residents living close to such industrial installations.

Funding: None.

Competing interests: None declared. 


\section{Accidents chimiques industriels : un risque sanitaire croissant en République islamique d'Iran}

\section{Résumé}

Contexte : Le nombre d'accidents chimiques en milieu de travail a augmenté au cours des dernières années en République islamique d'Iran. En juin et août 2015, trois explosions majeures se sont produites dans des entrepôts de produits chimiques de Rey, dans la province de Téhéran, provoquant le dégagement de vapeurs toxiques.

Objectifs : La présente étude s'est penchée sur les trois accidents chimiques et a évalué dans quelle mesure les exigences du Règlement sanitaire international (RSI) en matière de sécurité chimique et de préparation aux accidents chimiques sont respectées et mises en œuvre aux niveaux local et national en République islamique d'Iran.

Méthodes : Les données ont été obtenues en recourant à des données secondaires et des visites sur le terrain dans des usines chimiques sélectionnées. Les données secondaires ont été utilisées pour remplir une liste de contrôle en 33 items inspirée de la liste de contrôle du RSI et du ministère de la Santé et de l'Éducation médicale. Un échantillon de 15 entrepôts du district de Kahrizak, dans le comté de Rey, ont été visités pour évaluer leurs capacités au titre du RSI en utilisant une liste de contrôle en 15 items.

Résultats : Certaines faiblesses ont été identifiées dans la zone étudiée en ce qui concerne les capacités au titre du RSI. Les principales faiblesses étaient l'absence de systèmes efficaces pour la surveillance des accidents chimiques et le faible niveau de sécurité dans les entrepôts et les usines chimiques. Les autres faiblesses incluaient le manque de sensibilisation des résidents aux risques chimiques et la piètre qualité des équipements dont disposaient les centres de santé pour traiter les victimes d'accidents chimiques. La zone étudiée n'était pas préparée à faire face aux accidents chimiques dans les usines industrielles et les zones résidentielles.

Conclusions : Des mesures doivent être prises pour corriger les faiblesses observées et se conformer au RSI en mettant en place les capacités nécessaires en matière de sécurité chimique et de préparation et de riposte aux accidents chimiques.

$$
\begin{aligned}
& \text { الحوادث الكيميائية الصناعية: خطر صحي متزايد في جمهورية إيران الإسلامية }
\end{aligned}
$$

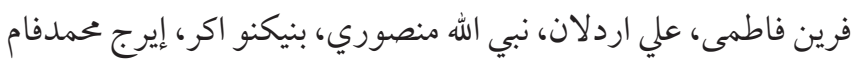

$$
\begin{aligned}
& \text { الخلاصة }
\end{aligned}
$$

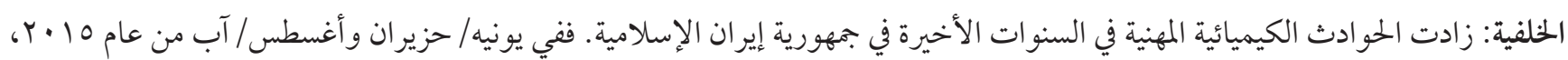

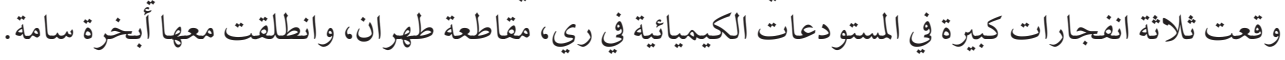

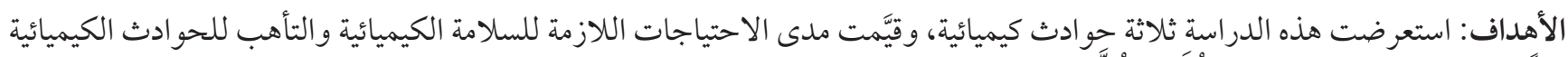

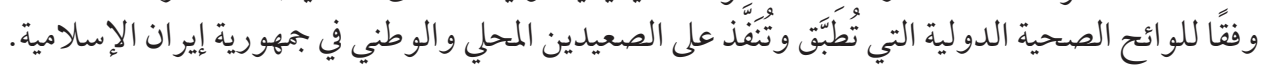

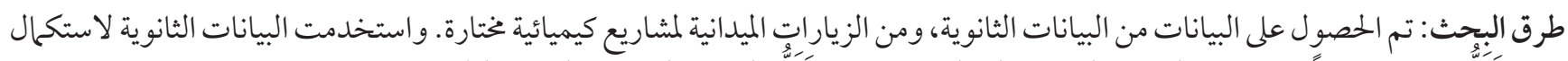

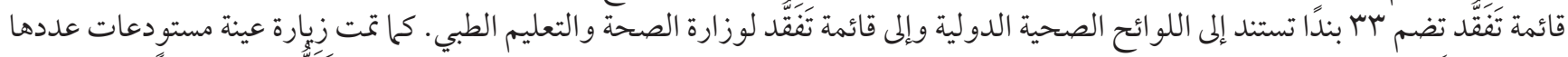

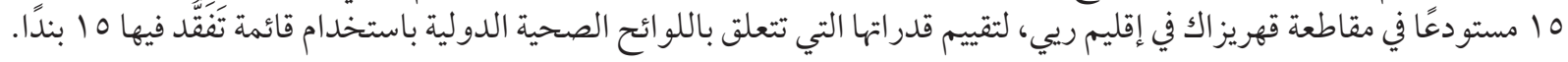
النتائج: شو هدت بعض مو اطن الضعف في القدر ات التي تتعلق باللو ائح الصحية الدولية في منطقة الدراسة. وكانت مو اطن الضعن الضعف الرئيسية هي

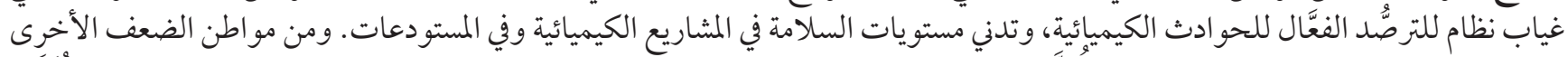

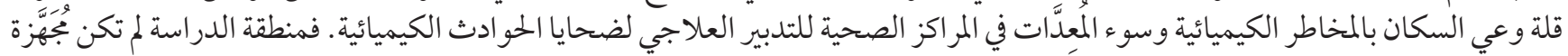

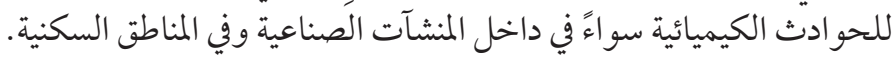

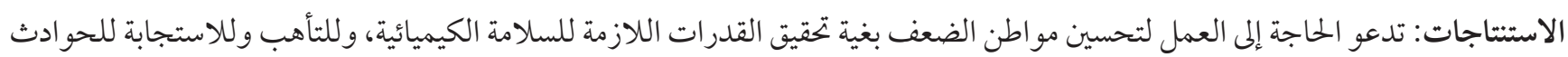

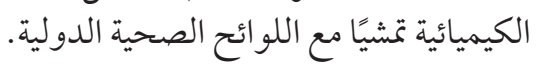

\section{References}

1. Sadeghi F, Bahrami A, Fatemi F. The effects of prioritize inspections on occupational health hazards control in workplaces in Iran. J Res Health Sci. 2014 Autumn;14(4):282-6. PMID:25503284

2. Mahdavi A, Azizmohammadlou H. The effects of industrialization on social capital: the case of Iran. Int J Soc Econ. 2013;40(9):777-96. https://doi.org/10.1108/IJSE-10-2012-0104

3. Giuffrida A, Iunes RF, Savedoff WD. Occupational risks in Latin America and the Caribbean: economic and health dimensions. Health Policy Plan. 2002 Sep;17(3):235-46. https://doi.org/10.1093/heapol/17.3.235 PMID:12135989 
4. Duan W, Chen G, Ye Q, Chen Q. The situation of hazardous chemical accidents in China between 2000 and 2006. J Hazard Mater. 2011 Feb 28;186(2-3):1489-94. https://doi.org/10.1016/j.jhazmat.2010.12.029 PMID:21239108

5. Zhou Y, Hu G, Li J, Diao C. Risk assessment along the gas pipelines and its application in urban planning. Land Use Policy. 2014;38(0):233-8. https://doi.org/10.1016/j.landusepol.2013.11.011

6. [Chemical accidents statistics during 2010-2013]. Tehran: Ministry of Labour; 2013. [In Farsi].

7. [Toxic gas lands 130 in hospital]. Kayhan news, 27 October 2014. [In Farsi].

8. Shaeri AM, Rahmati A. [Human's environmental laws, regulations, criteria and standards]. Tehran: Hak Publication; 2012. [In Farsi].

9. Meel A, O'Neill LM, Levin JH, Seider WD, Oktem U, Keren N. Operational risk assessment of chemical industries by exploiting accident databases. J Loss Prev Process Ind. 2007;20(2):113-27. https://doi.org/10.1016/j.jlp.2006.10.003

10. Li F, Bi J, Huang L, Qu C, Yang J, Bu Q. Mapping human vulnerability to chemical accidents in the vicinity of chemical industry parks. J Hazard Mater. 2010 Jul 15;179(1-3):500-6. https://doi.org/10.1016/j.jhazmat.2010.03.031 PMID:20363556

11. Sengul H, Santella N, Steinberg LJ, Chermak C. Accidental hazardous material releases with human impacts in the United States: exploration of geographical distribution and temporal trends. J Occup Environ Med. 2010 Sep;52(9):920-5. https://doi.org/10.1097/ JOM.obo13e3181f131dd PMID:20798641

12. Stewart-Evans J, Hall L, Czerczak S, Manley K, Dobney A, Hoffer S, et al. Assessing and improving cross-border chemical incident preparedness and response across Europe. Environ Int. 2014 Nov;72:30-6. https://doi.org/10.1016/j.envint.2014.03.012 PMID:24768281

13. Hendryx M, Fedorko E. The relationship between toxics release inventory discharges and mortality rates in rural and urban areas of the United States. J Rural Health. 2011 Winter;27(4):358-66. https://doi.org/10.1111/j.1748-0361.2011.00367.x PMID:21967379

14. Checklist and indicators for monitoring progress in the development of IHR core capacities in States Parties. Geneva: World Health Organization; 2013.

15. Jang N, Koo J, Shin D, Jo MS, Yoon Y, Yoon ES. Development of chemical accident database: considerations, accident trend analysis and suggestions. Korean J Chem Eng. 2012;29(1):36-41. https://doi.org/10.1007/s11814-011-0149-7

16. Han KH, Walker R, Kuhri M. An integrated response to chemical incidents-the UK perspective. Resuscitation. 1999 Oct;42(2):133-40. https://doi.org/10.1016/S0300-9572(99)00112-4 PMID:10617332

17. Olowokure B, Pooransingh S, Tempowski J, Palmer S, Meredith T. Global surveillance for chemical incidents of international public health concern. Bull World Health Organ. 2005 Dec;83(12):928-34. PMID:16462985

18. Bowen HJ, Palmer SR, Fielder HM, Coleman G, Routledge PA, Fone DL. Community exposures to chemical incidents: development and evaluation of the first environmental public health surveillance system in Europe. J Epidemiol Community Health. 2000 Nov;54(11):870-3. https://doi.org/10.1136/jech.54.11.870 PMID:11027203

19. Abbaspour M, Shafiepour M, Mansouri N. [The comprehensive program for controlling the environmental health hazards triggered by chemical accidents]. Environment health science and technology. 2003;21:1-9. [In Farsi].

20. He G, Zhang L, Lu Y, Mol APJ. Managing major chemical accidents in China: towards effective risk information. J Hazard Mater. 2011 Mar 15;187(1-3):171-81. https://doi.org/10.1016/j.jhazmat.2011.01.017 PMID:21255926

21. Shen Y, Wang Q, Yan W, Sun J. An evacuation model coupling with toxic effect for chemical industrial park. J Loss Prev Process Ind. 2015;33(0):258-65. https://doi.org/10.1016/j.jlp.2015.01.002

22. Quarantelli EL, Gray J. Research findings on community and organizational preparations for and responses to acute chemical emergencies. Columbus (OH): Disaster Research Center, The Ohio State University; 1984.

23. Manual for the public health management of chemical incidents. Geneva: World Health Organization; 2009.

24. What is CBRN? Dundas (Onatrio): Center for Excellence in Emergency Preparedness; 2012 (http://www.ceep.ca/education/CBRNintrosheet.pdf, accessed 3 April 2018).

25. Hazmat Team Planning Guidance. Washington, DC: Environment Protection Agency; 1990 (https://www.orau.org/ptp/PTP\%20 Library/library/DOE/emergency/epadoc.pdf, accessed 3 April 2018).

26. Duarte-Davidson R, Orford R, Wyke S, Griffiths M, Amlôt R, Chilcott R. Recent advances to address European Union Health Security from cross border chemical health threats. Environ Int. 2014 Nov;72:3-14. https://doi.org/10.1016/j.envint.2014.01.003 PMID:24679379

27. Gablehouse TR. The role of local communities in chemical accident prevention and preparedness. J Loss Prev Process Ind. 2005;18(4-6):549-52. https://doi.org/10.1016/j.jlp.2005.07.010

28. Phillips BD, Morrow BH. Social science research needs: focus on vulnerable populations, forecasting, and warnings. Nat Hazards Rev. 2007;8(3):61-8. https://doi.org/10.1061/(ASCE)1527-6988(2007)8:3(61). 